\title{
Reading Revelation from the top or the underside
}

\author{
De Villiers, Pieter GR \\ University of the Free State \\ pgdevilliers@mweb.co.za
}

\begin{abstract}
I dedicate this article to Allan Boesak on the occasion of his $70^{\text {th }}$ birthday in appreciation of his fearless struggle against racism, but also in gratitude for his many other writings in which he consistently promoted the cause of oppressed, vilified and abused groups in society in a truly compassionate and inspiring manner. This article also wishes to give recognition to his singular contribution to the study of Revelation, reflected in the many references to his commentary in scholarly works (cf. part 3 below).
\end{abstract}

Key words

Book of Revelation; hermeneutics; political contexts; literal reading; spiritual reading

\section{Introduction}

The reception history of Revelation is characterized by two major trajectories that interpret the book either literally or spiritually. Though they provide different, contrasting readings of the book, they mostly find, ironically, some common ground in their promotion or rejection of a political agenda. Their close, dynamic interaction with political contexts in many times and places explains why the interpretations varied from situation to situation. These different readings depended on specific interpreters and their contexts, all of which had political implications. ${ }^{1}$

Such readings were already evident from earliest times. Until recently they represent a pre-modern approach to Revelation: They apply the biblical text directly to the interpreter's context and take the text as authoritative

1 Cf. for a full discussion, Pieter GR de Villiers. Reading the Book of Revelation politically. SJT (2017). 
and directly relevant for their own time and situation. As time passed, the historical distance between the original text and later interpretations became more apparent so that interpreters wrestle in ever greater depth with the challenge of understanding Revelation in their own contexts, especially since and after the Enlightenment. Such changing circumstances and deeper insights contributed to symbolical and spiritual readings, mostly as referring to the church's spiritual journey. Such readings specifically criticized literal readings of Revelation by fringe groups and the common folk, often assuming that these readings questioned or endangered vested interests and positions of power within church and society.

Revelation's long history of political reception continues up to the present, but with a more complex nature. Major socio-political changes and postmodern theological discourse have brought about a new understanding of the nature of interpretation, drawing on insights from religious, theological, social, economic, political and other discourses. Many scholars now reflect on Revelation's relevance in terms of themes like violence against women and minority groups, or abuse of the economically deprived by powerful groups and political authorities. ${ }^{2}$ They approach the book in a more discerning way, abandoning facile, pre-modern and naive

2 Cf. for examples the essays in David Rhoades (ed.), From Every People and Nation: The Book of Revelation in Intercultural Perspective (Minneapolis: Fortress, 2005) for readings of Revelation from across the globe in various cultural settings and with many political implications. For an extensive discussion of Revelation's problematic portrait of women and its ideological underpinnings, cf. Tina Pippin, "The Heroine and the Whore: Fantasy and the Female in the Apocalypse of John". Semeia 60 (1992): 67-82, and her Death and Desire: The Rhetoric of Gender in the Apocalypse of John (Westminster/John Knox Press, Louisville, KY), 1992. Other informative texts that take into consideration the socio-political ramifications of the book are Carolyn Osiek, The Feminist and the Bible: Hermeneutical Alternatives (Scholars Press, Chicago, 1985). Elisabeth Schüssler Fiorenza, Revelation: Vision of a Just World (Fortress Press, Minneapolis, 1992). Adela Yarbro Collins, Persecution and Vengeance in the Book of Revelation in David Hellholm (ed.), Apocalypticism in the Mediterranean World and the Near East (Mohr Siebeck, Tübingen, 1983), pp. 729-748. How these readings reflect social developments in the twentieth century that contributed to new approaches to biblical exegesis and systematic theology, is explained in the discussion about the role and place of violence in the contemporary theological discourse by Pieter GR de Villiers, Towards a Spirituality of Peace, Acta Theologica Supplementum 11 (2008): 20-58. They also reflect the hermeneutics of suspicion that is critical of ideological and power games that are operative in theology and its foundational texts. Such hermeneutics are especially crucial for those interpreters of the bible that seek guidance in the spiritual wisdom of biblical texts for later times. 
readings. Revelation is now being read in a more sophisticated manner, based on a comprehensive hermeneutics that take into consideration the original context in which the book originated, the complexities involved in determining such a historical, literary and ideological reading, but also the very different situations and contexts in which the book's relevance for later times and readers is being considered and spelled out.

The comprehensive, often sophisticated nature of these new readings can be illustrated by the interpretation of Revelation by the South African theologian and political activist Allan Boesak. ${ }^{3}$ His book is an example of a contemporary political reading of Revelation by someone with an advanced theological training who sought to find meaning in it within complex, challenging and dangerous social discourse and setting.

His informed theological and biblical approach is evident from his decision to distance himself from both literalist and escapist readings of the book. Adopting established exegetical approaches, he locates the book within its historical context and interprets it in terms of the original communication situation with special attention to its political impact. Throughout the book, though, he consistently seeks to correlate that contextual analysis with a contemporary political exigence. His approach is one of deep involvement in the relevance of Scripture in a contemporary situation and is characterised by a conviction that Scripture has the potential to radically transform and empower its readers.

With this important publication, Boesak offers a glimpse in a more sophisticated political use of Revelation, which now needs some brief remarks. His work illustrates how the interpretation of Revelation is confronted with a new, very different challenge. It is namely increasingly being recognised that interpretation of the Bible is closely linked with and even determined by the context of interpreters. Methods like readers reception spelled out the role of the reader in interpretation and questioned the claims that understandings of the Bible should be done "objectively". It is, after all, impossible to eliminate the presuppositions and assumptions of interpreters. Ultimately all readings of the Bible have a contextual character.

3 Allan A Boesak, Comfort and Protest. The Apocalypse from a South African Perspective (Westminster Press, Philadelphia, P.A., 1987) 
This is especially true of Revelation. The book has become contentious as some scholars, mainly from privileged societies with open, vigorous democracies, began to question aspects of its ethos and message, claiming that parts of the book have serious implications for contemporary Christian existence. A prime example of such a reading was an essay by Adela Yarbro Collins in $1984^{4}$ that drew attention to and reflected uneasiness with the vengeful nature of the book, as will now be explained. ${ }^{5}$

This debate about the implications of Revelation's message has to do with social contexts in which there was a growing sensitivity for the violent nature of religious discourse. They became relevant especially in times that societies across the world were subjected to extreme forms of violence, often in political dispensations that were perpetrated in the name of religion, or, where the violence of political actions by governments was increasingly becoming a major social issue. ${ }^{6}$ Gradually the deeply ingrained violent nature of societies were being recognised and challenged by peace movements which early on only existed on the fringes of society in, for example, Mennonite churches. Discussions and reflections about violence in the Bible and by faith communities began to surface in the religious discourse of mainstream society and is currently a much discussed area of research. This growing interest in violence within the religious discourse followed the example of secular bodies like the United Nations that early

4 Adela Yarbro Collins, Crisis and Catharsis: The Power of the Apocalypse (Westminster Press, Philadelphia, 1984); cf. also Adela Yarbro Collins, 'Persecution and Vengeance in the Book of Revelation', in David Hellholm (ed.), Apocalypticism in the Mediterranean World and the Near East. Proceedings of the International Colloquium on Apocalypticism. Uppsala, August 12-17, 1979. J.C.B. Mohr, Tübingen, 1983), pp. 729-749.

5 For more information on these issues, cf. Pieter GR de Villiers, Persecution in the Book of Revelation. Acta Theologica 22 (2002): 47-70; Pieter GR de Villiers, "Hermeneutical Reflections on Violence in the New Testament", in Pieter GR de Villiers and JanWillem van Henten (eds.), Coping with Violence in the New Testament, (Leiden: Brill, 2013), pp. 245-273. For earliers, premodern interpretations of Revelation that reflect some concerns about its violent pronouncements, cf. Pieter GR de Villiers, Entering the corridors of power: State and church in the reception history of Revelation. Acta Theologica 33:2 (2013): 37-5. For more recent literature on the violent nature of Revelation, cf. De Villiers, Pieter GR, "The Violence of Nonviolence in the Revelation of John”. Open Theology 1:1 (2015): 189-203.

6 Many examples can be listed, but a case in point would by the violence that accompanied the civil rights movement and the Vietnam War in the United States - both of which remained in the spotlight in the media for many months and years. Cf. also the essays mentioned in the previous footnote where some of the many examples are pertinently listed. 
in the twentieth century exemplified the institutionalizing of the peace movements as a context in which conflicts could be resolved and global peace be promoted in a world riddled by extreme forms of violence. Much later the World Council of Churches also reflects this growing trend when it proclaimed a Decade against Violence at the beginning of the new millennium. Theology also began to pay major attention to the challenge of violence and the need to create awareness of its overt and covert forms. ${ }^{7}$ Adela Collins's article is an early example of the discussion within Biblical Studies as a discipline. It is striking that her discussion is focussed on Revelation, but more so, that it is such a central concern in a time that the book played such a prominent part in other global locations to empower communities to challenge extreme forms of political oppression and exploitation.

One way for Christians and churches of addressing the theme of violence was to find guidance and inspiration in Biblical texts, primarily in pronouncement about peace and in judgement of evil oppressors. Revelation was an obvious source of inspiration, as is clear from the witness of the German theologian, Bonhoeffer. He, who paid the highest price for his resistance to Nazism, spoke of the way in which Revelation inspired him in his struggle against Nazism. He hung on the wall of his cell a copy of Albrecht Dürer's Saint Michael Battling the Dragon in which the archangel Michael and three other angels fight a seven-headed dragon, relating Revelation to his own extreme political situation. ${ }^{8}$ His political reading of Revelation succoured the victims of the violent and racist political system of Nazism in his time. Bonhoeffer's understanding resonates with insights of many other readers for whom Revelation was an exceptional example of a non-violent lifestyle. ${ }^{9}$ Against this background it is indeed even more

7 Cf. for a full discussion, Pieter GR de Villiers, Towards a Spirituality of Peace, Acta Theologica Supplementum 11 (2008): 20-58.

8 Cf. Rivka Zim, Consolations of Writing: Literary Strategies of Resistance from Boethius to Bonhoeffer (Princeton University Press, Princeton, N.J., 2014), p. 54. She refers to his use of the Psalms in prison, omitting his own reference of the significant role of Revelation to him. Cf. Bonhoeffer's remarks in Letters and Paper from Prison (SCM Press, London, 1953), p. 128. For the role of Revelation in the Confessing Church, cf. also Boesak, Comfort, p. 39.

9 Cf., for example, Mark Bredin, Jesus, Revolutionary of Peace. A Nonviolent Christology in the Book of Revelation (Paternoster, Milton Keynes/Waynesboro, GA., 2003); Thomas 
striking that the book was increasingly being questioned by scholars from within Biblical Studies who pointed to its potential to incite violence, as will be discussed now. One has a situation in which the political reading of Revelation elicits major theological and ethical questions.

\section{Reading from the top}

Collins is a New Testament scholar who was trained and who lectured in a first world context with its established democracy and its institutions that promote and protect human rights, equality before the law and civil liberties for all its citizens. Her context, therefore, indicates progressive values of an open society, whilst her theological writings confirm her outstanding informed, enlightened and high quality critical scholarship.

Her essay notes how Revelation portrays the Roman Empire "in a highly unflattering light," predicting the destruction of Rome and its political and economic system. For her this raises concerns about the book's desire for revenge, not in the least because of the potential threat of such an attitude and language to socio-political institutions. She is particularly sensitive for the theological ramifications of this issue. The disturbing longing for vengeance has "most deeply offended the moral sensibilities of readers, Christian and non-Christian alike." To try and make sense of this phenomenon, she engages in a psychological analysis of Revelation's audience. They were under the impression that their Roman rulers and Jewish neighbours were hostile towards them as followers of Jesus. They found it difficult to cope with this perceived oppression because of its dissonance of such a situation with their faith in the coming of the divine kingdom. She points out that this is exacerbated by the fact that Revelation's vengeful response does not reflect real persecution, which makes the aggression and violence in the text so much more unacceptable and problematic. ${ }^{10}$ Collins proposes as reason for the vengefulness that

Yoder Neufeld, Jesus and the Subversion of Violence: Wrestling with the New Testament Evidence (SPCK, London, 2011).

10 Collins, Crisis, p. 168, rejects Barclay theory that the extreme and exploitative lifestyle of the city is one of the reasons why it is justly made an object of vengeance in the book, though she acknowledges that he also understood the complexities of the issue, clearly having "struggled most deeply with the harsh language." 
the author created the crisis and did so with the purpose to "awaken and intensify Christian exclusiveness, particularly vis-à-vis the imperial cult."11

She wants to give some credit to the author: The perceived or projected crisis can be viewed positively in so far as it helped the faith communities to resolve their anxiety and tension. And yet she points out how destructive this tension is because it dehumanizes people by dividing them in two camps and demonizing the dissenting group. Her comments indicate how Revelation can be seen to promote a lifestyle that is isolationist and could even be regarded as sectarian. Collins's reading of a perceived crisis is not new, as she points out when she documents several examples of theologians who grappled with the issue of the vengeful hatred in the book. She also has support from exegetes who concur that there is no historical evidence for official state sponsored political persecution by Roman authorities in the first century. ${ }^{12}$ Her reading of John's divisive handling of this perceived crisis, is also supported in scholarly discussions. In some instances it leads to a rather radical view of the book's continuing relevance and even questions its canonical status. The British author, Jonathan Knight referred to John's sectarian mind-set and his confusing outlook as main stumbling blocks for its appropriation in a contemporary context. According to him John's insistence that his readers avoid social integration with the pagan world in the Pauline sense, his strict prohibition of adopting pagan practices and his instruction to his followers to isolate themselves within their own group, is tantamount to a call to become a sectarian counter-community. He guided his flock, already in the minority, deeper into the wilderness of seclusion and isolation. For Knight this shows that he was close to the absolute sectarianism of the Qumran community that represents the logical conclusion of John's own position. ${ }^{13}$

In scholarly discussions the theories of a perceived crisis and of a sectarian mind-set have been questioned so that the notion that John created the crisis is not universally accepted. Backhaus, for example, associates the

11 Ibid., p. 73.

12 Cf. especially Leonard L. Thompson, The Book of Revelation: Apocalypse and Empire (Oxford University Press, Oxford, 1990).

13 Jonathan Knight, Revelation. Readings: A New Biblical Commentary, (Sheffield Academic Press, Sheffield, 1999), p. 29. 
book with an external and internal crisis. The external crisis is typical of a minority in so far as it reflects cultural pressures, social limitation, sporadic attacks, legal actions (e.g. exile), imprisonment and even capital punishment. Internally the church faced divisions regarding life in a pagan context. Rejecting the notion of a perceived crisis theory (20), Backhaus draws attention to the closing "The one who conquers"-formula at the end of each of the seven letters that reflects a context in which Christians faced real threats from their opponents. The realities of the emperor cult and the action of Jewish groups in the Roman Empire certainly also contributed to this serious situation. The church is under deadly attack (Rev. 6:1-8; 12; 13; 17), involved in a struggle for life and death, called to follow the Lamb wherever He goes (Rev.14:4) and to be with Him (Rev.17:14). ${ }^{14}$

Rather than discussing such research here in more depth, it is more useful in terms of this article to evaluate the deeper hermeneutical issue by comparing Collins' reading with a radically different political reading that has a very positive view of Revelation's tough language against the state, as will be done now. It is, however, clear that Collins's reading of Revelation reflects her sensitivity for the theological implications of exegetical praxis in Biblical Scholarship and for an approach that fails to recognize or tends to rationalize the harsh, violent language of Revelation. Her position also represents a timely warning against a religious discourse that may be abused to promote violence. Also important is that she raises the important issue of the ethics of Biblical Studies as a discipline, requiring from exegetes to not only analyse texts, but also to weigh them in terms of scholarly requirements for a humanising, ethical research praxis. Her essay provides important insights in the practice of appropriating Biblical texts, especially where they may negatively affect the place and role of society in the modern world.

14 For critique on the perceived persecution theory, cf. e.g., Kurt Backhaus, Die Vision vom Ganz Anderen, in Kurt Backhaus (Hrsg.), Theologie als Vision. Studien zur Johannes-Offenbarung (Katholisches Bibelwerk, Stuttgart, 2001), pp. 18-25 speaks of a "tiefgreifenden Krise" in which Christianity found itself at the time of the writing of this book. 


\section{Reading from the underside}

Allan Boesak is well-known as one of the key figures in the struggle against the infamous South African system of apartheid and institutionalized racism. After his university studies in South Africa, he graduated in the Netherlands with a thesis on Black Theology. ${ }^{15}$ During the darkest times of the struggle, Boesak wrote a commentary on Revelation with the telling title, Comfort and Protest: The Apocalypse from a South African Perspective. This creative political reading of Revelation is often cited in contemporary New Testament publications. ${ }^{16}$

A noteworthy characteristic of the book is that it reads Revelation from the underside, from the perspective of victims of an oppressive, undemocratic state with a long history of human rights abuses and institutional racist violence. ${ }^{17} \mathrm{He}$ approaches the book in terms of a close, careful analysis of his own context in which there is persistent oppression and persecution of those on the margins of society. One recognizes in this approach the see-judge-act method that is typical of contextual theologies. This perspective from the underside is enriched by Boesak's ability to expose deeper dynamics that drive abusive and totalitarian political systems and to describe oppression not only in terms of abusive military power, but also in terms of a wide range of economic, institutional, judicial and social injustices and abuses. His work further reflects extensive knowledge of biblical and systematic scholarship. ${ }^{18}$ His comprehensive approach is

15 Allan A. Boesak, Farewell to Innocence: A Socio-Ethical Study on Black Theology and Black Power (Orbis Books, Maryknoll, 1976).

16 Cf. e.g. Richard Bauckham, The Climax of Prophecy (T\&T Clark, London, 1993), 371; Ian Boxall, The Revelation of St. John.Black's New Testament Commentaries(Continuum, London, 2006), p. 11, 115, 134, 228; Harry O. Maier, Apocalypse Recalled. The Book of Revelation after Christendom (Fortress Press, Minneapolis, 2002), pp. 8, 30, 38; David L. Barr, Tales of the End. A Narrative Commentary on the Book of Revelation (Polebridge Press, Salem, OR, 2012), p. 38.

17 Boesak, Comfort, p. 25. "We read history not in terms of relative differences between oppressors but in terms of the reality of suffering and oppression, the joys and hopes of the little people of God. We see and understand the events of history from the underside. ... It is the fact that the weak and the destitute remained oppressed which provides the framework for understanding and interpreting history." Cf. also Comfort, 36 , where he repeats that his reflections rest on "biblical exegesis from the underside" with its contemporary meaning for the black church in South Africa as its target.

18 He carefully engages with various introductory issues, places the Bible in context, compares Revelation with other apocalypses, discusses in depth the nature and identity 
evident in his discussion of traditional and eschatological readings that have left Revelation "to the fanatics and the escapists, or the academics of rich countries who have time for games of empty speculation." ${ }^{19} \mathrm{He}$ also resonates with an important trend in hermeneutics, which insists that contemporary interpretations of the Bible should reflect and appropriate the transformative claims of biblical books. ${ }^{20} \mathrm{His}$ book rejects, for example, the eschatological trajectory in the reception history of Revelation, because such readings lack transformative and efficacious power.

The nature of the underside is reflected in his description of how Revelation has transformed him as a pastor and theologian. He reports conducting a series of Bible studies for a local church in the traumatic period of 1980, when young people who rose up against an abusive state were being oppressed and killed by sophisticated military machinery. ${ }^{21}$ The deadly events affected the spiritual well-being of society and faith communities, he writes, and left them scarred, with "many wounds that would never heal". Perhaps even more critically, they were confronted with profound "questions about faith and God". ${ }^{22}$ His reading of Revelation thus involved a lived encounter with the biblical text. It is the religious alienation of his times that opens his eyes for the meaning of Revelation.

of its authorship, time of its writing and other traditional introductory questions that are typical of biblical Scholarship. He also seeks to understand what it means to live in a first century context. Recalling a remark of Tertullian about the trend to blame Christians for everything that went wrong, he writes that Christians were not superheroes who were exceptionally brave: "They were ordinary people, wary of informers and turncoats, certainly not looking forward to the next round of torture, scared of those dark, dank (damp?), stinking cells, scared also of the loneliness of dying." Boesak, Comfort, p. 24.

19 Boesak, Comfort, p. 13. Cf. also his remarks on 38, where he refers to readings of Revelation that reflect sterile "escape mechanisms and dead-end arguments about numbers and symbols and signs by which the real message of Revelation is often paralyzed."

20 Cf. the powerful analysis in Sandra Schneiders, The Revelatory Text: Interpreting the New Testament as Sacred Scripture (HarperSanFrancisco, San Francisco 1991).

21 The Soweto uprisings were one of a number of major protest movements against the apartheid system. Others name by Boesak, Comfort, p. 69, were Sharpeville (1960), Cape Town (1980), Langa (1984). Cf. Boesak, Comfort, p. 83, for another discussion of the Soweto uprising.

22 Boesak, Comfort, p. 14. His comments here are explained on p. 37 where, amongst others, he refers to pastors who were imprisoned, church services banned, worshippers attacked with tear gas, dogs, and guns. Cf. also Comfort, pp. 48-49. 


\subsection{Comfort and protest}

Boesak's book, true to its title, reflects on how Revelation consoles and empowers people through its fearless exposure of an absolute, violent state in terms of seminal spiritual insights and themes. Those on the underside discover how Revelation addresses "the deepest questions about human history, about God and Israel, and about the lot of God's people in the world, their pain, humiliation, and suffering. Here are the questions about the love and power of the living God, who remains God even though that love and power seem to disappear under the tidal wave of blind rage that the persecutor spews forth". ${ }^{23}$ They are inspired by the book's prophetic challenge to godless political, social and economic forces and its quest for justice for exploited and dehumanized people. This focus on justice becomes the hermeneutical key for his understanding of Revelation. "Those who do not know this suffering through oppression, who do not struggle together with God's people for the sake of the gospel, and who do not feel in their own bodies the meaning of oppression and the freedom and joy of fighting against it shall have great difficulty understanding the letter from Patmos." ${ }^{24}$ On the deepest level, readers of Revelation are helped to recognize the religious nature of this desire for a just world. They learn to recognize the central role of a "political tyrant" as a blasphemer who arrogantly usurps the divine reign. "It is important to note that the tyrant is always in competition with God. Indeed, he sees himself as a god in the place of God, and he expects the honour and submission one owes a god - or, for the Jews and the Christians, God." ${ }^{25}$ With this insight, Boesak confirms a key notion in Revelation: it is a book about deception. The Empire claims even the allegiance of faith communities because it mimics in a satanic manner the divine nature and work, in the process deceiving people to commit themselves to an evil, abusive lifestyle.

\subsection{Economic reading}

Boesak's exposition of Revelation 17 illustrates the comprehensive nature of his analysis. His analysis is also determined by his conviction that

23 Boesak, Comfort, p. 16.

24 Boesak, Comfort, p. 38.

25 Boesak, Comfort, p. 17. 
economic conditions have vital political ramifications. He points out that Rome's powerful reign is intricately linked with material conditions and economic power, reflecting its vast resources and control of others. Once again he discusses this in terms of Revelation's context: John's claims about Rome's downfall are ironic, because on the surface, it would have appeared to readers that Rome was a superpower in full control.

In contrast, John challenges this economic claim by exposing the spiritual dynamic beneath the surface. In a liberating way, the author of Revelation points out that Rome's grip on power is an illusion. In reality, it is experiencing its last convulsions because its economic practices are corrupt and destructive. This is revealed in the collaborators' response to the fall of Babylon in Revelation 18: they pity themselves with their lament on the loss of their lucrative trade in luxurious, expensive commodities. In addition and most tellingly, they list the slave trade as the last of these commodities. This remark reveals the true character of Rome, which does not regard slaves as human beings. A slave, in their view, is but one of many commodities. The song that shows that goods and profits are more important than human beings for these collaborators of Rome, reveals a fundamental dehumanizing of the Other. ${ }^{26}$ Such a godless regime is destined for divine judgment. For Boesak, reading Revelation from the underside means discovering that God will remove from the face of the earth those who do not acknowledge and respect the dignity of others. It degrades the other to a commodity and objectifies them as but another possession.

\subsection{A global impact}

Boesak's commentary is written from a South African perspective, but is universal in its contents and appeal, resonating with readers across the world who are concerned about major political challenges like racial, gender, political and social oppression and violence. He consciously transcends a parochial approach, referring explicitly to forms of evil that are present not only in the South African context, but also worldwide. This includes the "modern gods" of racism, militarism, materialism, and oppressive exploitive political and economic powers that claim obedience, loyalty

26 Boesak, Comfort, pp. 120-121. 
and slavish submission. ${ }^{27} \mathrm{He}$ also integrates references to those who have heroically resisted these gods, including Walter Lüthi from the Confessing Church in Germany, who appealed to his churches to recognize Hitler as the beast who needed to be resisted actively, ${ }^{28}$ and radical disciples such as Bonhoeffer, Martin Luther King, Oscar Romero, Steve Biko, Kaj Munk and Olaf Palme. ${ }^{29}$ All of this shows his awareness of the complex nature of contemporary social discourses. Boesak's thorough analysis of systematic injustice and abuse as supported by an intricate network of institutions creates a framework in which Revelation is interpreted to transform and empower the oppressed, the persecuted and abused minorities. ${ }^{30}$

\section{Conclusion}

This overview shows confirms the contextual nature of Revelation's reception. Both readings of Boesak and Collins reflect careful, learned engagement with the text that is informed by various existing exegetical traditions. Both challenge the reader, however, not only to read the text with exegetical acumen, but ultimately to be especially conscious of one's own context and to what extent it allows one to read the text adequately. In this way, their readings relate to lived experiences. Both readings reflect an existential engagement with the text, conscious of its socio-political potential to determine or transform the praxis of faith communities. And both readings show that one can no longer claim to be applying "the" meaning of a text to one's own context in order to explain its relevance. The

27 Cf. Boesak, Comfort, p. 69, for his remarks about racist colonial oppression over a period of three and a half centuries.

28 Boesak, Comfort, p. 39.

29 Boesak, Comfort, p. 89.

30 David Lerton Matson. “'Outside are the Dogs." Interpreting Revelation's Hate Language'. Leaven 8.1 (2000): 43 has made some seminal remarks about the impact and relevance of a literal reading of Revelation's end time language: "Divorced from Revelation's suffering context, these words can come off sounding self-serving and vitriolic. We're right, they're wrong! We win, they don't! Many white, middle-class Christians who read Revelation to satisfy their curiosity about end-time matters might do well to listen to other readers of the book, those persons and groups who more easily identify with the social location of Revelation. As Hays observes, 'Something very strange happens when this text is appropriated by readers in a comfortable, powerful, majority community: it becomes a gold mine for paranoid fantasies and for those who want to preach revenge and destruction.'” 
above discussion shows how one's own context decisively determines "the" meaning of the text. Who the reader is, co-determines what the text means.

Finally, it is striking that both the readings of Boesak and Collins reflect a strong ethical character. Ironically, both of them, though very different, are directed against mindless violence and abuse. Boesak's integrity is clear from his fearless witness against a violent, tyrannical and racist state, whilst Collins takes up a strong position against facile, but dangerous use of violent language and the harbouring of vengeful, adversarial attitudes. Both of them rely on information that comes from the biblical text itself.

It happens, therefore, that some interpreters can claim "Revelation" as a text with a prophetic witness about a particular cause, whilst others use it for a different, even conflicting, but equally legitimate and ethical reading. It follows from this that the text is, therefore, ambiguous and even frail, reflecting not only inspiring moments, but also insights that can leave the reader disillusioned. This is a liberating insight, making us aware of how human the biblical prophets were. That is one reason why the greater wisdom of faith communities resulted in the text being integrated in a larger collection of foundational texts, implying that the book should be read within that larger context and should be illuminated or corrected by the other parts of the collection. Whilst Boesak's important work makes one aware or the liberating function of Revelation in a situation of institutionalized oppression and explains why it has been an inspiration to many generations of believers, Collins's exegesis reminds one of those parts that we tend to overlook and that require us to witness differently, but also fearlessly against overt and covert forms of abuse that escape our attention and hides behind our own holy claims and judgements. The one reading looks outwards, addressing mindless and vengeful violence of evil people and institutions, the other reading looks inwards, analysing the inner feelings that express themselves in and drive what we say and do. Both readings can, therefore, be liberating. The one helps us to stand up against the corrupt and abusive destroyers of the earth. The other one helps us to look at the way we witness against evil and calls us to do so without becoming as violent as the perpetrators of violence. Both of them caution against facile readings that read the book in a literalist, harmless and overpious manner. 


\section{Bibliography}

Backhaus, Kurt. „Die Vision vom Ganz Anderen“, in Kurt Backhaus (Hrsg.), Theologie als Vision. Studien zur Johannes-Offenbarung, (Katholisches Bibelwerk, Stuttgart, 2001), 18-25.

Barr, David L. Tales of the End. A Narrative Commentary on the Book of Revelation. (Polebridge Press, Salem, OR, 2012).

Bauckham, Richard. The Climax of Prophecy (T\&T Clark, London, 1993).

Boesak, Allan A. Farewell to Innocence: A Socio-Ethical Study on Black Theology and Black Power (Orbis Books, Maryknoll, 1976).

Boesak, Allan A. Comfort and Protest. The Apocalypse from a South African Perspective (Westminster Press, Philadelphia, P.A, 1987).

Boxall, Ian. The Revelation of St. John Black's New Testament Commentaries (Continuum, London, 2006).

Bredin, Mark. Jesus, Revolutionary of Peace. A Nonviolent Christology in the Book of Revelation (Paternoster, Milton Keynes/Waynesboro, GA., 2003).

Collins, Adela Yarbro. Crisis and Catharsis: The Power of the Apocalypse, (Westminster Press, Philadelphia, 1984).

Collins, Adela Yarbro. "Persecution and Vengeance in the Book of Revelation" in David Hellholm (ed.), Apocalypticism in the Mediterranean World and the Near East (Mohr Siebeck, Tübingen, 1983), 729-748.

De Villiers, Pieter GR. "Persecution in the Book of Revelation". Acta Theologica 22 (2002), 47-70.

De Villiers, Pieter GR. "Hermeneutical Reflections on Violence in the New Testament", in Pieter GR de Villiers and Jan-Willem van Henten (eds.), Coping with Violence in the New Testament (Leiden: Brill, 2013), 245-273.

De Villiers, Pieter GR. "Entering the corridors of power: State and church in the reception history of Revelation". Acta Theologica 33:2 (2013), 37. 
De Villiers, Pieter GR. "The Violence of Nonviolence in the Revelation of John”. Open Theology 1:1 (2015): 189-203.

De Villiers, Pieter GR. "Reading the Book of Revelation politically". SJT (2017).

De Villiers, Pieter GR. “Towards a Spirituality of Peace”. Acta Theologica Supplementum 11 (2008), 20-58.

Knight, Jonathan. Revelation. Readings: A New Biblical Commentary (Sheffield Academic Press, Sheffield, 1999).

Landes, Richard Allen, Andrew Colin Gow, David C Van Meter (eds.). The Apocalyptic Year 1000: Religious Expectation and Social Change (Oxford University Press: Oxford, 2003), 950-1050.

Landes, Richard Allen. "Introduction: The Terribles Espoirs of 1000 and the Tacit Fears of 2000", in Richard Allen Landes, Andrew Colin Gow, David C Van Meter (eds.), The Apocalyptic Year 1000: Religious Expectation and Social Change, 950-1050 (Oxford University Press, 2003): Oxford. 3-16.

Maier, Harry O. Apocalypse Recalled. The Book of Revelation after Christendom (Fortress Press: Minneapolis, 2002).

Matson, David Lerton. ““'Outside are the Dogs.” Interpreting Revelation's Hate Language". Leaven 8.1 (2000): 40-47.

Neufeld, Thomas Yoder. Jesus and the Subversion of Violence: Wrestling with the New Testament Evidence (SPCK: London, 2011).

Osiek, Carolyn. The Feminist and the Bible: Hermeneutical Alternatives (Scholars Press: Chicago, 1985).

Pippin, Tina. "The Heroine and the Whore: Fantasy and the Female in the Apocalypse of John Semeia 60 (1992): 67-82.

Pippin, Tina. Death and Desire: The Rhetoric of Gender in the Apocalypse of John (Westminster/John Knox Press: Louisville, KY, 1992) Rhoades, David (ed.). From Every People and Nation: The Book of Revelation in Intercultural Perspective (Minneapolis: Fortress, 2005). 
Schneiders, Sandra. The Revelatory Text: Interpreting the New Testament as Sacred Scripture (San Francisco: Harper SanFrancisco, 1991).

Schüssler Fiorenza, Elisabeth. Revelation: Vision of a Just World (Minneapolis: Fortress Press, 1992).

Thompson, Leonard L. The Book of Revelation: Apocalypse and Empire (Oxford: Oxford University Press, 1990).

Zim, Rivka. Consolations of Writing: Literary Strategies of Resistance from Boethius to Bonhoeffer (Princeton, NJ: Princeton University Press, 2014). 